\title{
Characteristics of the Psidium cattleianum (Myrtaceae) Seed Bank in Hawaiian Lowland Wet Forests ${ }^{1}$
}

\author{
Amanda L. Uowolo ${ }^{2,3}$ and Julie S. Denslow ${ }^{3}$
}

\begin{abstract}
Psidium cattleianum Sabine (strawberry guava) is one of Hawai'i's most disruptive alien plants. Dense stands can suppress growth and establishment of native species, support high populations of crop-damaging fruit flies, and preclude restoration or management of native forests. Our research investigated factors affecting persistence of $P$. cattleianum seeds in lowland wet forest soils. We collected soil cores from four forested sites immediately after fruit fall and 6.5 months later. We found abundant germination of P. cattleianum seeds immediately after fruit drop. Soil collected under mature $P$. cattleianum clumps yielded 761 viable seeds $/ \mathrm{m}^{2}$. We found no viable seeds 6.5 months after fruit drop. We evaluated seed longevity using seed bags buried below the litter layer that we retrieved after 28,56,196, and 365 days. Seeds either germinated or deteriorated rapidly after fruit drop; after 28 days, $22.3 \%$ of the buried seeds were viable and there were no viable seeds at 196 days. Predator effects were assessed using trays with a known number of seeds with and without predator exclosures. After 28 days, $37 \%$ of the seeds in the open trays were damaged by predators. The lack of a persistent seed bank likely is due to a combination of rapid, high germination rates, postdispersal seed predation, and seed mortality. We suggest that chemical or mechanical control efforts would be most efficient and effective if conducted at least 3 months after the fruiting season, when the vast majority of seeds have either germinated or died.
\end{abstract}

Psidium cattleianum SABIne (Myrtaceae), also known as strawberry guava, is considered one of Hawai'i's most severe invasive weeds (Smith 1985, Wagner et al. 1999, Motooka et al. 2003). Psidium cattleianum is common on all the major Hawaiian islands and throughout the Pacific where it continues to increase in density and impact. Rapid growth rates (J.S.D. and A.L.U., unpubl. data), prolific fruit production, and high rates of suckering produce dense stands quickly from small populations (Huenneke and Vitousek 1990). Psidium cattleianum is a serious threat to native forest ecosystems in Hawai' $i$ and

${ }^{1}$ Manuscript accepted 26 April 2007.

${ }^{2}$ Corresponding author (e-mail: auowolo@fs.fed.us).

${ }^{3}$ Institute of Pacific Islands Forestry, U.S. Department of Agriculture Forest Service, 60 Nowelo Street, Hilo, Hawai'i 96720.

Pacific Science (2008), vol. 62, no. 1:129-135

Work of the U.S. Government

Not under copyright elsewhere in the Pacific due to its ability to invade even relatively undisturbed wet forests and form dense thickets (Smith 1985, Huenneke and Vitousek 1990). The fruits of P. cattleianum support high populations of fruit flies (e.g., Dacus dorsalis Hendel) that are considered one of the most important agricultural pests in Hawai'i (Vargas et al. 1990). The efficacy of any control method for $P$. cattleianum is influenced by the characteristics of its seed bank, because a persistent seed bank contributes to high population growth rates and reduces the likelihood of local eradication. We investigated longevity of seeds of Psidium cattleianum in Hawaiian soils, the characteristics of the seed bank, and factors affecting the duration of seeds in lowland wet forest soils in Hawai'i.

\section{MATERIALS AND METHODS}

Species Description

Psidium cattleianum has invaded native Hawaiian ecosystems ranging from moist to very 
wet conditions from 15 to $1,300 \mathrm{~m}$ elevation (Jacobi and Warshauer 1992, Wagner et al. 1999). All forms of P. cattleianum grow as shrubs or small trees, typically $2-6 \mathrm{~m}$ tall in mesic to wet forests in Hawai $i$ (Wagner et al. 1999). We used seeds from the common round, yellow-fruited form (P. cattleianum $\mathrm{f}$. lucidum Degener) in this study. Fruits contain 15-70 angular seeds (Diong 1982, Huenneke and Vitousek 1990) of $2.5-5 \mathrm{~mm}$ in length (Morton 1987, Wagner et al. 1999). Peak fruit fall typically occurs between June and December (Diong 1982, Huenneke and Vitousek 1990). Psidium cattleianum seeds are readily spread by humans and feral pigs (Sus scrofa) (Diong 1982, Jacobi and Warshauer $1992)$ as well as by a variety of birds (Medeiros 2004).

\section{Study Area}

Study sites were established within the Upper Waiākea Forest Reserve $\left(19^{\circ} 35^{\prime} \mathrm{N}, 155^{\circ} 12^{\prime}\right.$ W), the Pu'u Maka'ala Natural Area Reserve $\left(19^{\circ} 34^{\prime} \mathrm{N}, 155^{\circ} 12^{\prime} \mathrm{W}\right)$, the 'Ōla'a Forest Reserve $\left(19^{\circ} 27^{\prime} \mathrm{N}, 155^{\circ} 11^{\prime} \mathrm{W}\right)$, and the Kahauale'a Natural Area Reserve $\left(19^{\circ} 26^{\prime} \mathrm{N}\right.$, $155^{\circ} 10^{\prime} \mathrm{W}$ ) on the island of Hawai' $\mathrm{i}$. All sites are on windward Hawaici Island at approximately $900 \mathrm{~m}$ elevation. Estimated annual rainfall is $3,000-4,000 \mathrm{~mm}$ at 'Ōla'a and Kahauale'a and 4,000-5,000 $\mathrm{mm}$ at Upper Waiākea and $\mathrm{Pu}^{\text {'u }}$ Maka'ala (Giambelluca et al. 1986). Projected mean annual temperature based on adiabatic lapse rates is $17-17.5^{\circ} \mathrm{C}$ for the elevation range of the four study sites (Giambelluca and Schroeder 1998). All of the study sites are on relatively young tholeiitic basalt lava flows that formed $200-1,500 \mathrm{yr}$ B.P. (Wolfe and Morris 1996). The soils at Upper Waiākea and Pu'u Maka'ala are deep and well drained (Typic Udifolists, U.S. Department of Agriculture Natural Resource Conservation Service [USDA-NRCS], unpubl. data) over weathered ' $a \bar{a}$ lava. The soils at Kahauale'a (Lithic Hapludands, USDANRCS, unpubl. data) and 'Ōla'a (Lithic Udifolists, USDA-NRCS, unpubl. data) are very shallow to shallow, moderately well-drained soils formed in volcanic ash deposited over pāhoeboe lava bedrock. The forests are classified as native lowland wet forests with an 'ōhi'a (Metrosideros polymorpha Gaud.) lowland wet forest community type (Gagné and Cuddihy 1999).

\section{Seed Longevity}

Seed longevity of P. cattleianum in soil was assessed by tracking the fates of known numbers of seeds placed in bags and inserted under the litter at each of the four study sites. Fully ripened and intact $P$. cattleianum fruits were collected from and beneath trees in October and pooled from multiple P. cattleianum groups across 'Ōla'a Forest Reserve. Seeds were immediately cleaned, air dried, and stored for 1 week in an air-conditioned environment. Percentage seed viability was assessed on a subsample of the pooled seeds (10 replicates of 50 seeds each) 1 week after the seeds were collected and on the same day the seed bags were placed in the field. At each study site, one set of four seed bags was placed under each of five groups of large $P$. cattleianum trees. Each sealed bag (6 by 7.5 $\mathrm{cm}, 86-$ mesh silkscreen fabric) contained 20 seeds and $5 \mathrm{~g}$ of sieved, autoclaved soil. The bags were placed beneath the litter layer (generally $2.5-5 \mathrm{~cm}$ deep) in contact with the soil surface and were placed in the field during the fruiting season in late October. One seed bag from each of the five sets of bags placed at each site was retrieved after $28,56,196$, and 365 days. When the buried bags were retrieved, the seeds were evaluated and seeds that had germinated or decayed were separated from those that were intact. Intact seeds were tested for viability by planting in sterile growing medium in a greenhouse under irrigation and approximately $53 \%$ sun. Germination of seeds was monitored over a 16-week period.

The buried bags provided information on changes in the numbers of viable, persistent seeds and seed decay and senescence over time. We modeled the decline in numbers of viable seeds as an exponential decay function (SigmaPlot 8.02 [SPSS Inc. 19862001]):

$$
y=y_{0} e^{-k t}
$$

in which $y$ is the number of the original seeds remaining and persisting as viable seeds in the 
soil at time $t, y_{0}$ is the number of seeds at time $0, t$ is the elapsed time in days, and $k$ is the decay constant. The mean residence time (MRT) is calculated:

$$
\operatorname{MRT}=1 / k
$$

The seed bags excluded mammalian and many invertebrate predators from access to the seeds but did not prevent infestation by soil fungi; therefore, $k$ and mean residence time represent longevity of the seeds in the soil in the absence of predators.

\section{Seed Bank}

We collected four soil cores $\left(500 \mathrm{~cm}^{3}\right.$, to 5 $\mathrm{cm}$ deep) from beneath each of five clusters of mature $P$. cattleianum trees from each of the four study sites on each collection date. We selected $P$. cattleianum tree clusters with canopies exposed to full sun to maximize the probability of sampling where trees had generated dense seed shadows. Soils were collected twice: immediately after fruit fall (late November) and approximately 6.5 months after fruit fall (early June). The soil from each core was spread to a depth of $1 \mathrm{~cm}$ over sterile medium and placed in the greenhouse under irrigation and approximately $53 \%$ sun. Psidium cattleianum germinants were counted and removed weekly over a 16-week period.

\section{Seed Predation Rates}

We compared rates of seed damage to protected and unprotected seeds spread on trays placed in the forest. Twenty trays (43 by 43 by $5 \mathrm{~cm}$ deep) containing $50 P$. cattleianum seeds each were placed at each of the four study sites; half of these trays were covered with hardware cloth $(6.35-\mathrm{mm}$ mesh) to exclude large predators and half were left open. Open and protected trays were placed adjacent to one another, but $10 \mathrm{~m}$ away from the canopy of P. cattleianum trees to avoid additional seed input from fruit fall. The seeds placed in the trays were from the same composite sample of seeds used in the buried seed bags and were cleaned, air dried, and stored for 1 month in an air-conditioned environment until the seeds were placed in the field. Forest floor litter material was placed in the trays with the seeds, and the trays were lined with $2 \mathrm{~mm}$ nylon mesh to prevent washout. Trays were placed in the field in late November at the end of the fruiting season at all study sites. After 28 days, the trays were collected, seeds and litter material were separated, and seeds were counted and evaluated for evidence of predation. We assumed that secondary seed dispersal did not occur and, by extension, that missing seeds had been consumed and not dispersed as viable seeds. Seeds with evidence of animal activity (i.e., teeth marks, seed fragmentation) were considered damaged and were assumed to be nonviable as well. Data from one subsequently overturned tray were excluded.

\section{Data Analysis and Synthesis}

We used the data from the seed longevity and seed predation experiments to develop a projection of the fate of $P$. cattleianum seeds 6.5 months after fruit fall. The baseline germination trial was used to estimate the percentage of nonviable seeds in the seed rain. Data from the buried seed bags provided information on persistent, viable seeds in the seed bank. Seeds recovered intact in the seed bags were considered persistent or viable if they subsequently germinated in the greenhouse. Seeds that did not germinate in the seed bags while in the field nor in the greenhouse when removed from the bags were considered to have died. The exclosure experiment provided the rate of predation; we assumed that all predation occurred during the 28-day period following seed dispersal. We assumed that nongerminating seeds from the seed bags included those that were nonviable in the seed rain and that a certain percentage of seeds that subsequently germinated in the seed bags in the field would have been lost to mammalian and invertebrate predators in the first month.

RESULTS

\section{Seed Longevity}

Results from the buried seed bags showed that the decrease in viable seeds with time followed an exponential decay curve $(y=$ 86.41 $e^{-0.0463 t}, r^{2}=0.99, P=<.0001$ ) (Figure 


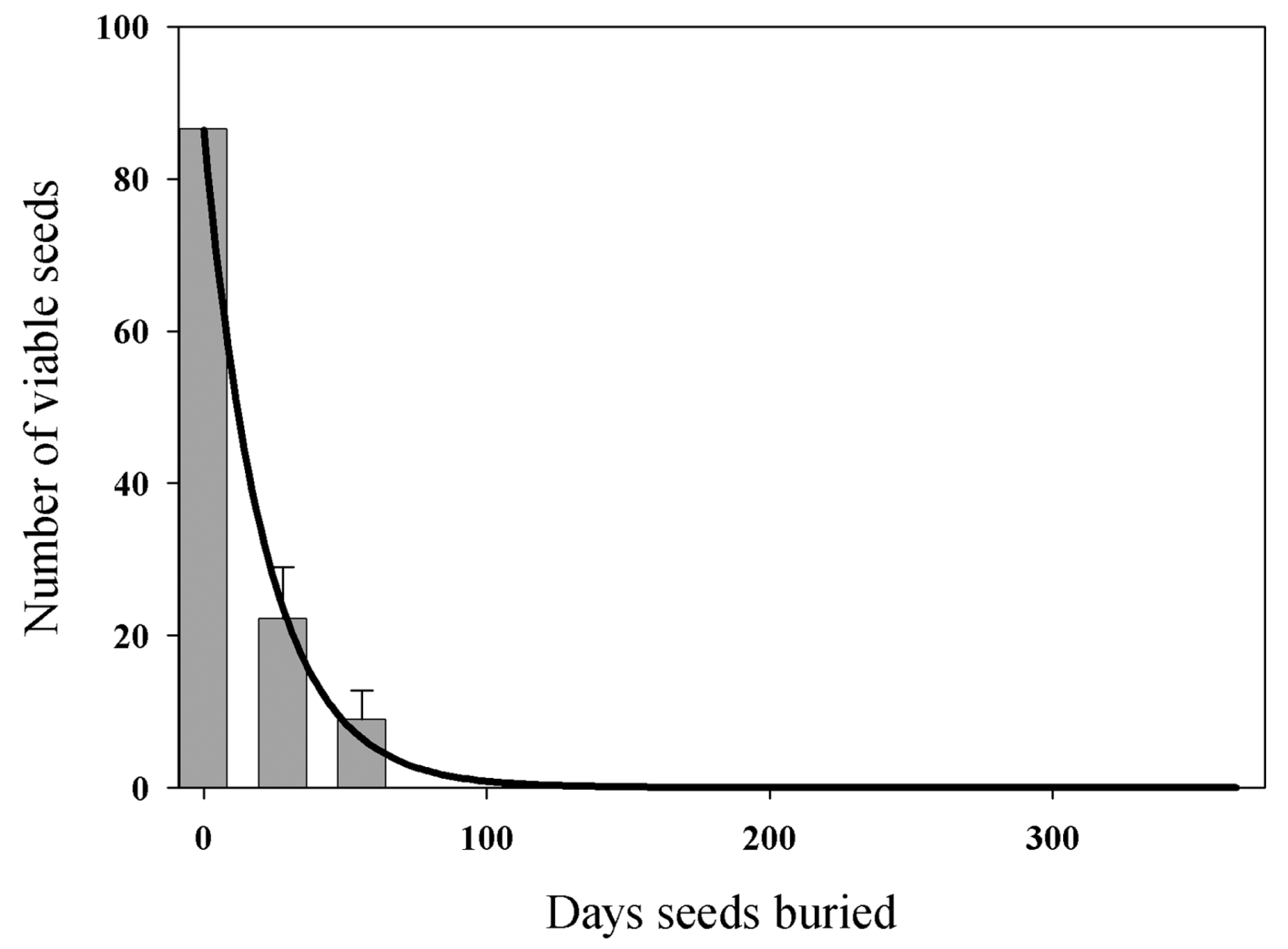

FIGURE 1. Mean number of $P$. cattleianum seeds (per 100 seeds) germinating after being buried in seed bags. Baseline viability was assessed when the bags were buried (day 0), and bags were collected after 28, 56, 196, and 365 days. Error bars represent the standard error among four study sites. There were no viable seeds in the bags collected after 196 and 365 days.

1). Mean residence time for the seeds was 21.6 days. In the absence of predation, $95 \%$ of the seeds had either germinated in the field or lost viability in 66 days; $99 \%$ of the seeds were nonviable after 96 days.

\section{Seed Bank}

High numbers of viable $P$. cattleianum seeds were found in soil collected during fruit fall at our sites (761 viable seeds $/ \mathrm{m}^{2}, n=4$ sites, $\mathrm{SE}=309$ ), yet no viable seeds were found from soil collected 6.5 months after peak fruiting season. Results from the soil samples collected 6.5 months after fruit drop were consistent with results from the seed bags retrieved after 6.5 months; in neither case was there evidence of a persistent seed bank.

\section{Seed Predation Rates}

A mean of $36.9 \%(n=4$ sites, $\mathrm{SE}=7.1)$ of the seeds in open trays were missing or damaged by predators after 28 days in the field. The amount of seeds missing or damaged by predators ranged from 0 to $90 \%$ in the open trays. Less than $0.1 \%$ of seeds $(n=4$ sites, $\mathrm{SE}=0.05$ ) were missing from the protected trays after the same time period.

\section{Seed Fates}

Figure 2 summarizes the fates of $P$. cattleianum seeds in lowland wet forests 6.5 months after dispersal. At 196 days, 28 seeds out of 100 placed in the bags were dead when recovered, having failed to germinate when placed 


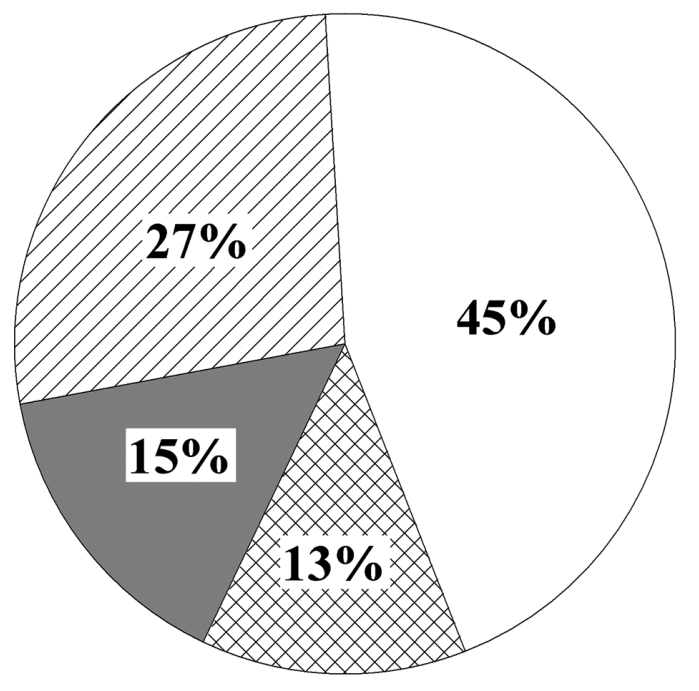

$\square$ Seeds germinating in the field
$\square$ Seeds lost to predation
Seeds dying
$\square \times x$ Seeds nonviable in seed rain

Figure 2. Projected fates of $P$. cattleianum seeds 6.5 months after dispersal into lowland Hawaiian forest soils.

in the greenhouse. We assumed that 13 of those seeds had been nonviable in the seed rain and estimated therefore that 15 seeds had died after being placed in the field. The remaining 72 seeds germinated in the field before the bags were recovered. We assumed that $36.9 \%$ or 27 of those would have been lost to predation in the first month following dispersal, leaving an estimated 45 seeds germinating in the field. Dead and nonviable seeds also lost to predation (36.9\% of 13 nonviable and 15 dead seeds) are not shown in Figure 2. We estimate that most $P$. cattleianum seeds were lost from the seed bank due to predation and germination, with smaller percentages nonviable from pre- or postdispersal processes. We found no evidence of viable seeds 6.5 months after fruit fall.

\section{DISCUSSION}

Seeds of tropical rain forests may have the shortest ecological longevity of seeds of any plant community (Vasquez-Yanes and
Orozco-Segovia 1993). The absence of persistent seed banks among trees in tropical systems has been attributed to predation (Thompson 1987) and to simultaneous and rapid germination of the seeds immediately after dispersal (Vasquez-Yanes and OrozcoSegovia 1993) or in response to favorable ephemeral conditions (Skoglund 1992). Although many seeds of tropical and subtropical rain forest trees are desiccation tolerant (orthodox) and thus have the potential to form persistent seed banks in the soil (Vasquez-Yanes and Orozco-Segovia 1996, Tweedle et al. 2003, Dalling 2005), most tropical rain forest plants do not do so (Hopkins and Graham 1987, Thompson 1987, Skoglund 1992, Vasquez-Yanes and OrozcoSegovia 1993). Psidium cattleianum, with orthodox seeds (Becwar et al. 1983), appears to be typical of most tropical trees. Desiccation tolerance in the laboratory is not necessarily correlated with the persistence of the seeds in the field (Tweedle et al. 2003) because seeds in the natural environment are subject to predation, invertebrate and microbial infection, and conditions conducive to germination. Germination and predation appear to account for the majority of the loss of $P$. cattleianum seeds from soils of Hawaiian lowland wet forests.

Although our study did not identify the seed predator(s), damage was typical of that by rodents. Black rats (Rattus rattus), house mice (Mus musculus), and Polynesian rats (Rattus exulans) are known seed predators in Hawaiian forests and are an important constraint on reproduction of native plants (Tomich 1986, Cuddihy and Stone 1990, Cabin et al. 2000). Rodents have been shown to be effective predators of exotic plant seeds in Hawaiian forests as well (Medeiros 2004), and P. cattleianum seeds may be a readily available food source for alien rodents. Predation rates are likely to be spatially variable; a previous study found no evidence of $P$. cattleianum seeds in rodent droppings at another site (Medeiros 2004).

Results from the buried seed bags suggest that even in the absence of predation $P$. cattleianum seeds do not survive burial in natural conditions for an extended period of time. 
The persistence of seeds has been shown to increase with an increased depth of burial (Toole and Brown 1946, Lonsdale et al. 1988), and we might have found P. cattleianum seeds to have been viable longer if our seeds had been buried more deeply. Despite the many combinations of variables that may have affected the outcome of the buried bag experiment, the lack of any viable seeds in the soil samples we collected 6.5 months after fruit drop suggests that seeds do not naturally persist from one fruiting season to the next in the soil environment. In two other studies where soil cores were collected from forests with mature $P$. cattleianum plants present, viable $P$. cattleianum seeds were not encountered either (Huenneke and Vitousek 1990, Drake 1998).

An understanding of local $P$. cattleianum phenology and the characteristics of the seed bank is of value in the selection and scheduling of control methods for this invasive plant. Because most $P$. cattleianum seeds do not live beyond 3 months in the soil, chemical or mechanical control efforts would be most efficient and effective if conducted at least 3 months after the fruiting season. The biological control agent Tectococcus ovatus is currently proposed for the control of $P$. cattleianum in Hawai'i and has been documented to reduce fruit and seed production of plants in Brazil (Johnson 2005). Our results suggest that a biocontrol agent that reduced $P$. cattleianum seed production would also rapidly deplete soil seed stocks, therefore increasing effectiveness of chemical and mechanical control.

\section{ACKNOWLEDGMENTS}

We thank the Division of Forestry and Wildlife of the State of Hawai'i for access to field sites. We are grateful to Cheyenne Perry, Roddy Nagata, Wendell Sato, and Kim Buzdygon for their assistance in the field, greenhouse, and/or laboratory.

\section{Literature Cited}

Becwar, M. R., P. S. Stanwood, and K. W. Leonhardt. 1983. Dehydration effects on freezing characteristics and survival in liquid nitrogen of desiccation tolerant and desiccation-sensitive seeds. J. Am. Soc. Hortic. Sci. 108:613-618.

Cabin, R. J., S. G. Weller, D. H. Lorence, T. W. Flynn, A. K. Sakai, D. Sandquist, and L. J. Hadway. 2000. Effects of longterm ungulate exclusion and recent alien species control on the preservation and restoration of a Hawaiian tropical dry forest. Conserv. Biol. 14:439-453.

Cuddihy, L. W., and C. P. Stone. 1990. Alteration of native Hawaiian vegetation: Effects of humans, their activities, and introductions. University of Hawai'i Cooperative National Parks Resources Studies Unit. University of Hawai'i Press, Honolulu.

Dalling, J. W. 2005. The fate of seed banks: Factors influencing seed survival for lightdemanding species in moist tropical forests. Pages 31-44 in P. M. Forget, J. E. Lambert, P. E. Hulme, and S. B. Vander Wall, eds. Seed fate: Predation, dispersal, and seedling establishment. CABI Publishing, Cambridge, United Kingdom.

Diong, C. H. 1982. Population biology and management of the feral pig (Sus scrofa) in Kipahulu Valley, Maui. Ph.D. diss., University of Hawai'i at Mānoa, Honolulu.

Drake, D. R. 1998. Relationships among the seed rain, seed bank, and vegetation of a Hawaiian forest. J. Veg. Sci. 9:103-112.

Gagné, W. C., and L. W. Cuddihy. 1999. Vegetation. Pages 45-114 in W. L. Wagner, D. R. Herbst, and S. H. Sohmer. Manual of the flowering plants of Hawai'i. Bishop Museum Special Publication 87. University of Hawai'i Press and Bishop Museum Press, Honolulu.

Giambelluca, T. W., M. A. Nullet, and T. A. Schroeder. 1986. Rainfall atlas of Hawai' $i$. R 76. Department of Land and Natural Resources, Division of Water and Land Development, State of Hawai'i, Honolulu. Giambelluca, T. W., and T. A. Schroeder. 1998. Climate. Pages 49-59 in S. P. Juvik and J. O. Juvik, eds. Atlas of Hawai'i. 3rd ed. University of Hawai'i Press, Honolulu. Hopkins, M. S., and A. W. Graham. 1987. The viability of seeds of rainforest species 
after experimental soil burials under tropical wet lowland forest in north-eastern Australia. Aust. J. Ecol. 12:97-108.

Huenneke, L. F., and P. M. Vitousek. 1990. Seedling and clonal recruitment of the invasive tree Psidium cattleianum: Implications for management of native Hawaiian forests. Biol. Conserv. 53:199-211.

Jacobi, J. D., and F. R. Warshauer. 1992. Distribution of six alien plant species in upland habitats on the island of Hawai'i. Pages 155-188 in C. P. Stone, C. W. Smith, and T. Tunnison, eds. Alien plant invasions in native ecosystems of Hawai' $i$. University of Hawai'i Press, Honolulu.

Johnson, M. T. 2005. Petition for field release of Tectococcus ovatus (Homoptera: Eriococcidae) for classical biological control of strawberry guava, Psidium cattleianum Sabine (Myrtaceae), in Hawai'i. http://www.fs.fed.us/psw/topics/ecosystem processes/tropical/invasive/ (accessed 11 January 2007).

Lonsdale, W. M., L. S. Harley, and J. D. Gillett. 1988. Seed bank dynamics in Mimosa pigra, an invasive shrub. J. Appl. Ecol. 25:963-976.

Medeiros, A. C. 2004. Phenology, reproductive potential, seed dispersal and predation, and seedling establishment of three invasive plant species in a Hawaiian rainforest. Ph.D. diss., University of Hawai'i at Mānoa, Honolulu.

Morton, J. 1987. Cattley guava. Pages 363364 in Fruits of warm climates. Julia F. Morton, Miami, Florida.

Motooka, P., L. Castro, D. Nelson, G. Nagai, and L. Ching. 2003. Weeds of Hawai'i's pastures and natural areas. College of Tropical Agriculture and Human Resources, University of Hawai'i at Mānoa, Honolulu.

Skoglund, J. 1992. The role of seed banks in vegetation dynamics and restoration of dry tropical ecosystems. J. Veg. Sci. 3:357-360. Smith, C. W. 1985. Impact of alien plants on
Hawai'i's native biota. Pages 180-250 in C. P. Stone and J. M. Scott, eds. Hawai'i's terrestrial ecosystems: Preservation and management. University of Hawai'i Cooperative National Parks Resources Studies Unit. University of Hawai'i Press, Honolulu.

SPSS, Inc. 1986-2001. SigmaPlot, version 8.02 for Windows. Point Richmond, California.

Thompson, K. 1987. Seeds and seed banks. New Phytol. 106:23-34.

Tomich, P. Q. 1986. Mammals in Hawai'i. 2nd ed. Bishop Museum, Honolulu.

Toole, E. H., and E. Brown. 1946. Final results of the Duvel buried seed experiment. J. Agric. Res. 72:201-210.

Tweedle, J. C., J. B. Dickie, C. C. Baskin, and J. M. Baskin. 2003. Ecological aspects of seed desiccation sensitivity. J. Ecol. 91:294-304.

Vargas, R. I., J. D. Stark, and T. Nishida. 1990. Population dynamics, habitat preference, and seasonal distribution patterns of Oriental fruit fly and melon fly (Diptera: Tephritidae) in an agricultural area. Environ. Entomol. 19:1820-1828.

Vasquez-Yanes, C., and A. Orozco-Segovia. 1993. Patterns of seed longevity and germination in the tropical rainforest. Annu. Rev. Ecol. Syst. 24:69-87.

1996. Comparative longevity of seeds of five tropical rain forest woody species stored under different moisture conditions. Can. J. Bot. 74:1635-1639.

Wagner, W. L., D. R. Herbst, and S. H. Sohmer. 1999. Manual of the flowering plants of Hawai'i. Bishop Museum Special Publication 87. University of Hawai'i Press and Bishop Museum Press, Honolulu.

Wolfe, E. W., and J. Morris. 1996. Geologic map of the island of Hawai'i. Map 12524A. U.S. Department of the Interior, U.S. Geologic Survey Miscellaneous Investigations Series. 
